\title{
Our experience with optical diagnostics of the head and neck
}

\author{
Colin Hopper*, Waseem Jerjes, Tahwinder Upile \\ From 2nd Scientific Meeting of the Head and Neck Optical Diagnostics Society \\ San Francisco, CA, USA. 23-24 January 2010
}

Optical diagnostics have proved to be a reliable resource that can be used to provide an instant diagnosis of soft and, more recently, hard tissue diseases. In the field of head and neck malignancy, most of the experimental spectroscopy work has been performed using fluorescence spectroscopy, Raman spectroscopy, elastic scattering spectroscopy, microendoscopy and optical coherence tomography. These have all shown a marked increase in the sensitivity and specificity when compared to both clinical examination and frozen section analysis.

Optical biopsies can be acquired through different modalities; each has it own mechanism of action and requires different modes of data analysis. However, they share the ability of being able to provide a real time, non-invasive and in situ optical signature. Most of these techniques have been applied only in clinical trials and are yet to be employed in clinical practice, with the exception of fluorescence spectroscopy. Results from these trials are very promising and current results indicate the possibility of these techniques being applied in clinical practice in the next few years. This could have a great impact on diagnostics, by reducing the histopathology workload, reducing patient's anxiety, and allowing rapid surgical or adjuvant intervention.

Elastic scattering spectroscopy (ESS) has proved to be a promising method for detecting premalignant and malignant changes in oral tissues, with high sensitivity and specificity. Several head and neck tissues, including lymph nodes and bones, have been interrogated using ESS, which detects changes at the cellular and subcellular level, with very promising results. Fluorescence spectroscopy, unlike ESS, can identify changes through the fluorophores detected in the tissue, and has been found to be very accurate in detecting oral dysplasia. Raman spectroscopy can detect biochemical changes in tissue,

\footnotetext{
UCL Department of Surgery, University College London Medical School,
} London, UK but it has limited clinical applications due to its weak signal. The first application of microendoscopy in the head and neck was described by Upile et al. at University College Hospital, London; resected tumour margins were examined and the results were impressive. However, a fundamental understanding of histopathology is essential for achieving a high sensitivity and specificity. The preliminary results from the application of optical coherence tomography in the head and neck are promising and clinical trials continue.

We describe our experience in the clinical application of elastic scattering spectroscopy, fluorescence spectroscopy, microendoscopy and optical coherence tomography in the head and neck.

Published: 29 October 2010

doi:10.1186/1758-3284-2-S1-01

Cite this article as: Hopper et al:: Our experience with optical diagnostics of the head and neck. Head \& Neck Oncology 2010 2(Suppl 1):01.

\section{Submit your next manuscript to BioMed Central and take full advantage of: \\ - Convenient online submission \\ - Thorough peer review \\ - No space constraints or color figure charges \\ - Immediate publication on acceptance \\ - Inclusion in PubMed, CAS, Scopus and Google Scholar \\ - Research which is freely available for redistribution \\ Submit your manuscript at www.biomedcentral.com/submit}

